\title{
Pharmacokinetic Concentration Character Result in Standard Format
}

National Cancer Institute

\section{Source}

National Cancer Institute. Pharmacokinetic Concentration Character Result in Standard

Format. NCI Thesaurus. Code C87950.

The standard character or string for representation and reporting of pharmacokinetic concentration data. 